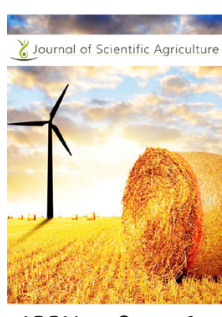

ISSN: $2184^{-0} 0261$

\title{
Variability in cooking time, iron and zinc content in common bean (Phaseolus Vulgaris L.) genotypes
}

\author{
I. Mughi',2, M. Ochwo-Ssemakula', R. Edema', P. Gibson'1 and C. Mukankusi² \\ ${ }^{1}$ School of Agricultural Sciences, Makerere University, P.O. Box 7062 Kampala, Uganda, ${ }^{2} \mathrm{ClAT}$ - Uganda, National \\ Agricultural Research Laboratories- Kawanda, P. O. Box 7065, Kampala, Uganda
}

\begin{abstract}
Prolonged cooking time leads to structural changes at the grain cellular level, resulting in loss of nutrients such as iron $(\mathrm{Fe})$ and zinc $(\mathrm{Zn})$ which are among the main nutrients important in addressing micronutrient malnutrition. The aim of this study was to evaluate the diversity of cooking time, Fe and Zn content in a total of 152 common bean (Phaseolus vulgaris) genotypes from around Eastern Africa, in order to identify short cooking genotypes with high Fe and $\mathrm{Zn}$ content. Field trials were conducted at CIAT-Uganda research station over two seasons in 2016. Cooking time was estimated using an automated Mattson cooker at CIAT-Uganda while Fe and Zn content was determined using XRF analysis at Rwanda Agricultural Board (RAB) in Rubona. A wide variability was evident from the test genotypes both for cooking time and mineral concentration. Cooking time exhibited a continuous distribution ranging from 35-100 minutes for the first season and 43-122 minutes for the second season. Seventy-three percent of the test genotypes had Fe levels higher than the low Fe check, CAL $96(55 \mathrm{mg} / \mathrm{kg}$ ) which is popularly known as 'Nambale' and a popular commercial variety in Uganda. A total of 15 genotypes (Amahunja, Awash melka, Bihogo, CAB 2, ECAPAN021, G858, Icaquimbaya, KK20, NABE12C, NABE4, NABE6, ROBA-1, RWR1873, RWV3006) were consistent in short cooking time for the two seasons and had a Fe content above the low Fe check (CAL96 - 55 mg/kg). A high correlation $(\mathrm{r}=0.7 \mathrm{l})$ was observed between Fe and $\mathrm{Zn}$ whereas a low correlation between cooking time and $\mathrm{Fe}(\mathrm{r}=-0.04)$ and $\mathrm{Zn}(\mathrm{r}=0.04)$ was observed. Great variability was evident for both traits indicating possible improvement by breeding and thus the possibility of having short cooking common bean genotypes with high Fe and Zn content.
\end{abstract}

KEYWORDS: Cooking time, diversity, micro nutrients, genotypes

I. Mughi,

Email: irene.mughi@gmail.

com

Received: October 22, 2020 Accepted: February 04, 2021 Published: March 03, 2021

\section{INTRODUCTION}

Cooking time of common bean (Phaseolus vulgaris L.) is an important feature in many countries in Africa and Latin America where the dry seeds are a dietary staple and firewood is the main fuel source used for cooking (Carbonell, 2003). The scarcity of firewood due to restrictions on deforestation in Eastern Africa has made the reduction in resources required to prepare beans for eating an important economic consideration . In addition, the rapid rate of urbanization and participation of women into the labor market has led to major changes into the food habits of the population. This has led to a demand for energy efficient and less time in food preparation (Zilio et al., 2014). Cooking times for beans can vary from $11 / 2$ to 8 hours, depending on the variety and the cooking method used (Zilio et al., 2014). Fast cooking bean cultivars compared to the cultivars currently grown for consumption may be a means to conserve firewood. In addition, the Eastern Africa countries place a lot of emphasis on attaining food security and adequate nutrition for its citizens. In
Uganda, persistent undernutrition in children is a perilous issue given that $33 \%$ of children under five years are stunted and $14 \%$ are underweight (USAID, 2016). In addition, undernutrition is a core cause of $60 \%$ of deaths for children under five years. Micronutrient deficiencies, including vitamin $\mathrm{A}$ and $\mathrm{Fe}$, are highly prevalent in women and children (USAID, 2016).

Long cooking beans have been shown to have more structural changes at the grain cellular level, resulting in a loss of nutrients such as iron $(\mathrm{Fe})$ and zinc $(\mathrm{Zn})$ compared to short cooking beans (Wiesinger et al., 2015). To combat the micronutrient malnutrition problem, research plays a key role in scaling up the production and marketing of biofortified crops like orange-fleshed sweet potato rich in Vitamin A and beans biofortified with Zn and Fe (USAID, 2016). Breeding progress for improving any trait is proportionate with the amount of genetic variability in the population.

Assessing genetic variability for a trait requires screening or evaluation of large amounts of germplasm. Based on the high

Copyright: ๑) The authors. This article is open access and licensed under the terms of the Creative Commons Attribution License (http://creativecommons.org/licenses/by/4.0/) which permits unrestricted, use, distribution and reproduction in any medium, or format for any purpose, even commercially provided the work is properly cited. Attribution - You must give appropriate credit, provide a link to the license, and indicate if changes were made. 
consumption of beans in East Africa, this study was conducted to investigate the genetic variability in cooking time, Fe and $\mathrm{Zn}$ in bean seed grown and consumed in Eastern Africa.

\section{MATERIALS AND METHODS}

One hundred and fifty-two (152) common bean genotypes were evaluated; 121 bush beans and 31 climbers. This germplasm consisted of released bean (commercial) varieties from seven East African countries (Table 1), Ethiopia, Madagascar, Uganda, Kenya, Tanzania, Rwanda and Burundi (PABRA, 2015). Breeding parents for important traits commonly used by members of the Pan-Africa Bean Research Alliance (PABRA) being maintained in the regional common bean gene bank at International Centre for Tropical Agriculture (CIAT) station based at the National Agricultural Research Laboratories (NARL) at Kawanda in Uganda were also included.

\section{Trial Establishment}

Two separate field trials were set up at Kawanda; one for the bush beans and another for the climbers for the ease of management practices and to reduce on inter-plot interference likely to occur if planted in one trial. Kawanda is located in Wakiso district in central Uganda, at Latitude $0^{\circ} 23^{\prime} 39^{\prime \prime}$ North, Longitude $32^{\circ}$ 32' 11 " East. It stands at an elevation of $1193 \mathrm{~m}$ above sea level, with the mean annual rainfall of $1250 \mathrm{~mm}$, daily temperatures average $15.3^{\circ} \mathrm{C}$ minimum and $27.3^{\circ} \mathrm{C}$ maximum, relative humidity of $76.3 \%$ and soil that is of a sandy loam type with $\mathrm{pH}$ of 5.5-6.0 (Fallingrain, 2015). The trials were set up during the 2015B season (April to July) and 2015D (September-December ), using a $6 \times 21$ alpha lattice design with three replications for bush beans on a plot of five rows each measuring two meters and a spacing of $10 \mathrm{~cm} \times 50 \mathrm{~cm}$ and a $3 \times 9$ alpha lattice with three replications for climber beans at $20 \mathrm{~cm} \times 50 \mathrm{~cm}$. NPK fertilizer(17:17:17) was applied at the rate of $100 \mathrm{~kg} / \mathrm{ha}$ during planting (PABRA,2015). Weed control was done using selective chemical, Bean Clean (Clethodim 240g/L) a broad spectrum herbicide that is selective on beans only followed by manual weeding. Routine spraying against pest and diseases was done weekly from three weeks after planting to when the beans reach physiological maturity, using Ridomil (Mancozeb, 2g/L) and Rocket insecticide (Cypermethrin $50 \mathrm{~g} / \mathrm{L}$ ).

These genotypes were evaluated alongside six Fe seed content checks, $\{$ (Climbers: MIB 456= universal high Fe, RWV1129= regional high $\mathrm{Fe}$ (East Africa) and Decelaya = universal low Fe: Bush beans: RWR2154= regional high Fe and DOR 500; universal low Fe and CAL 96; regional low Fe. No established checks exist for cooking time.

\section{Soil Sampling and Analysis}

Soil samples were obtained from the trial site by random sampling a week after planting the experiments. Soil samples were obtained at $0-20 \mathrm{~cm}$ depth. The samples were analyzed for, $\mathrm{pH}$, exchangeable magnesium $(\mathrm{Mg})$, calcium $(\mathrm{ca})$, potassium $(\mathrm{K})$, available phosphorus $(\mathrm{P})$, total organic carbon, and total nitrogen $(\mathrm{N})$; at Kawanda Agricultural Research Laboratories (KARL) following the Soils and Soil Fertility Management Programme protocol of National Agricultural Research Laboratory, Kawanda. The soil pH was determined using the Hl 9017 Microprocessor pH meter in 1:2.5 suspension of soil and water. Exchangeable bases (Ca, Mg, $\mathrm{K}$ and $\mathrm{Na}$ ) in the soil were determined in $1.0 \mathrm{M}$ ammonium acetate extract (Okalebo et al., 2002) by flame photometry $\left(\mathrm{K}^{+}, \mathrm{Na}^{+}\right)$and atomic absorption spectrophotometry $\left(\mathrm{Ca}^{2+}, \mathrm{Mg}^{2+}\right)$. Available P was extracted using the Mehlich-3 extraction method with $\mathrm{pH} 2.5$. Soil organic matter was analyzed using the Walkey Black method, nitrogen was analyzed using sulphuric/selenium digestion mixture, digested at $330^{\circ} \mathrm{C}$ and later quantified calorimetrically using the Nesler method. For $\mathrm{Fe}\left(\mathrm{Fe}^{2+}\right)$ and $\mathrm{Zn}$ determination, undiluted sample extracts were

Table 1 : Description of germplasm used in this study

\begin{tabular}{|c|c|c|}
\hline Origin & Official Name & Desired trait \\
\hline BURUNDI & $\begin{array}{l}\text { AND10, BIHOG0, G685, KATX69**, KATB1**, KATB9**, KATX56**, } \\
\text { MSO'LE**, MUKUNGUNGU, VCB81013, GASIRIDA, GLP2**, } \\
\text { HM21-7, MAC 44**, NAKAJA**, NGWAKU-NGWAKU**, RWR2154**, } \\
\text { RWR2245** }\end{array}$ & $\begin{array}{l}\text { Drought tolerant High Fe and Zn content, } \\
\text { high yield, }\end{array}$ \\
\hline D.R. CONGO & $\begin{array}{l}\text { ACC714, AFR708, AND10** CAL143, CNF5520 G685**, G2858, G2333, } \\
\text { JESCA MAHARAGI SOJA, CODMLB001, G858, GLP2**, MLB49-89A, } \\
\text { M'SOLE, NAKAJA NGWAKU-NGWAKU, ROBA-1, NUA45, ZEBRA**, } \\
\text { HM21-7, RANJONOBY** }\end{array}$ & $\begin{array}{l}\text { High } \mathrm{Fe} \text { and } \mathrm{Zn} \text { content, pest and disease } \\
\text { resistant, high yield, adaptation, short } \\
\text { maturity time, market type, low soil fertility } \\
\text { tolerance }\end{array}$ \\
\hline ETHIOPIA & AWASH 1, AWASH MELKA, ROBA-1 & Market type, drought tolerant \\
\hline MADAGASCAR & RANJONOMBY* & Disease resistant \\
\hline KENYA & $\begin{array}{l}\text { G2333, G685**, GLP2**, KATB1**, KATB9*, KATX69, KATX56, KK20, } \\
\text { KK8, MLB-49-89A, RWR1092, SCAM-80CM/15, ZEBRA** }\end{array}$ & $\begin{array}{l}\text { Pest and disease resistant, high yield, } \\
\text { adaptation, short maturity time, market } \\
\text { type }\end{array}$ \\
\hline RWANDA & $\begin{array}{l}\text { G2333, GASIRIDA, MAC42, MAC44**, MLB49-89A, RWR2154**, } \\
\text { RWR2245**, RWV2887, RWV3006, RWV3316, RWV1129 }\end{array}$ & $\begin{array}{l}\text { High Fe and Zn content, and market type, } \\
\text { yield, drought tolerant }\end{array}$ \\
\hline TANZANIA & A197 (S.TZ), JESCA* (N.TZ), ROBA-1 & $\begin{array}{l}\text { High yield, fast cooking and drought } \\
\text { tolerant }\end{array}$ \\
\hline UGANDA & $\begin{array}{l}\text { K131, K132, GLP2**, NABE1, NABE10C, NABE12C, NABE13, NABE14, } \\
\text { NABE16, NABE17, NABE18, NABE19, NABE2, NABE21, NABE22, } \\
\text { NABE23, NABE3, NABE4, NABE5, NABE7C, NABE8C, NABE9C, } \\
\text { NABE26C }\end{array}$ & $\begin{array}{l}\text { Market, high yield, pest and disease drought } \\
\text { tolerant }\end{array}$ \\
\hline
\end{tabular}


directly aspirated into the atomic absorption spectrophotometer (SHIMADZU AA-6800) and read at 248.3nm and 213.86nm (Gerwing \& Gelderman, 2005).

\section{Cooking Time Estimation}

Seed samples for cooking time estimation were obtained on plot basis, thus every entry was replicated thrice. The plants were harvested by uprooting the whole plant by hands per plot basis followed by machine threshing and cleaning. Thereafter, the seeds were bulked per plot then sun dried to $12-13 \%$ moisture content. Twenty-five seeds per plot were randomly picked and weighed using a top-pan balance to obtain weight before soaking. The seeds were then soaked for twelve hours in distilled water and re-weighed to obtain the weight after soak. The amount of water absorbed was scored by obtaining the difference in weight before and after soak and expressed as a percentage (Elia, 2003). Thereafter the seeds were placed in each of the 25 cylindrical holes of an automated Mattson Bean cooker developed by Canadian Grain Commission (Winnipeg, Canada) (Proctor \& Watts, 1987) using a burner set at $350{ }^{\circ} \mathrm{C}$ and cooking timing started. A Mattson cooker consists of 25 plungers or pins and a cooking rack with 25 reservoir-like perforated saddles, each of which holds a pulse seed and a plunger calibrated to a specific weight. Each plunger terminates in a stainless steel probe $2.0 \mathrm{~mm}$ in diameter. The cooker is a stand-alone machine monitored by a computer and the test results are automatically recorded on the computer. Cooking time is calculated as when $80 \%$ of the beans are soft enough to be pierced through by the plunger, this is an equivalent of when the $20^{\text {th }}$ of the 25 pins of the cooker has penetrated the seed (Wang \& Daun, 2005).

\section{Seed Iron (Fe) and Zinc (Zn) Analysis}

Samples consisting of forty to fifty seeds (depending on the seed size) were randomly picked from each plot bag and packed in small envelopes after being surface cleaned by rubbing between clean cotton cloths dampened with distilled water for 60 seconds. A new piece of clean cloth was used for each sample and care was taken to thoroughly clean hands before conducting the activity. According to Paltridge et al. (2011) this process reduces Aluminum $(\mathrm{Al})$ contamination from approximately $15 \mathrm{ppm}$ to 2 ppm and by about 5 ppm for Fe contamination while $\mathrm{Zn}$ remains unchanged. Thereafter, each sample was oven-dried at $60^{\circ} \mathrm{C}$ for at least 12 hours, and then ground using a Sunbeam Conical Burr Mill EM0480 Grinder (Sunbeam, Australia). Ground samples were stored in newly labeled paper bags and transported to the Rwanda Agricultural Board - Rubona station at the National Gene bank of Rwanda for XRF analysis. Care was taken to clean the grinder between samples using a brush and vacuum (Stangoulis, 2010). The ground sample to be analyzed was then carefully transferred into small sample cups on the tray, positioned in the XRF machine's tray (Acute instruments, Mumbai, India) and identified by labeling samples on the screen tray with the sample number. The amount of Fe and Zn was determined by XRF spectrometry by scanning each sample for 100 seconds with spinning of sample cup to analyze Fe and Zn content and records intensities of emitted X-rays (Oxford Instruments, 2009). Standard samples were run after every 100 samples to standardize the machine and to have confidence in results.

\section{Data Analysis}

Genotype effects for all data including cooking time, $\mathrm{Fe}$ and $\mathrm{Zn}$ were subjected to analysis of variance (ANOVA) statistical procedure of Gen Stat (12 ${ }^{\text {th }}$ Edition, VSN International Ltd. Copyright, 2009). Differences in means between genotypes were separated using the Least Significant Difference (LSD) test.

\section{RESULTS}

The experimental soils had acidic soils, low soil phosphorus 7.7-7.9 ppm (though not critical) and low K ppm during both seasons. The concentration of minerals such as $\mathrm{Ca}, \mathrm{Mg}$ and $\mathrm{Zn}$ were not sufficient. Organic matter $(6.5 \%)$, nitrogen $(0.31 \%)$ and Fe (259.0ppm) concentrations were high to very high and sufficient. The sites did not differ significantly in terms of the soil properties (Table 2).

The analysis of variance revealed high significant differences $(\mathrm{P}<0.001)$ in genotypes, seasons and genotype by season interaction for cooking time in bush beans and significant $(\mathrm{P} \leq 0.05)$ genotype effects for climber beans (Table 3$)$. There was a wide variation in cooking time among the 152 test genotypes in both seasons. For the first season (2015B) which is a normal rainy season with an average rainfall of $690 \mathrm{~mm}$, cooking time ranged between 35 (Awash melka) and 100 minutes (VAX4) with an average of 56 minutes. Twenty-four percent $(24 \%)$ of the genotypes had cooking time of less than $45(<45)$ minutes, $49 \%$ with $46-60$ minutes and $27 \%$ with $>60$ minutes.

In the second season (2015D), a normal rainy season with an average of $489 \mathrm{~mm}$, the cooking time among the 152 genotypes

Table 2: Status of the soil from the experimental site

\begin{tabular}{|c|c|c|c|c|}
\hline Soil component & 2015B Measurements & 2015D Measurements & Critical values & Sufficient levels for beans \\
\hline $\mathrm{pH}$ & 4.95 & 4.2 & 5.2 & $5.2-7.0$ \\
\hline OM (\%) & 6.5 & 5.7 & 0.2 & 0.3 \\
\hline N (\%) & 0.31 & 0.38 & 3 & 6 \\
\hline$P(p p m)$ & 7.9 & 7.7 & 5 & 20 \\
\hline $\mathrm{Ca}(p p m)$ & 1488 & 1598.77 & 150 & 500 \\
\hline $\mathrm{Mg}(\mathrm{ppm})$ & 408.8 & 389.64 & 100 & 600 \\
\hline K (ppm) & 35.11 & 339.64 & 350 & 2000 \\
\hline $\mathrm{Fe}(p p m)$ & 259.9 & 161 & 5.5 & 50 \\
\hline Zn (ppm) & 1.65 & 5.4 & 4 & 20 \\
\hline
\end{tabular}

*Ppm -parts per million; OM -Organic matter 
Mughi, et al.

Table 3: Mean squares for cooking time (minutes) of 121 bush and 31 climbing bean genotypes

\begin{tabular}{lccccc}
\hline SOV & \multicolumn{2}{c}{ Bush } & & \multicolumn{2}{c}{ Climbers } \\
\cline { 2 - 3 } \cline { 6 - 6 } & DF & CT & & DF & CT \\
\hline Season & 1 & $99126^{*}$ & & 1 & 665 \\
Rep/Season & 4 & $2522^{* * *}$ & & 4 & $665^{*}$ \\
Genotype & 120 & $1075^{* * *}$ & & 30 & $674^{*}$ \\
Genotype. Season & 120 & $462^{* * *}$ & & 30 & 217 \\
LEE & 99 & 311.0 & & 31 & 127.8 \\
SED & & 9 & & 9 \\
\%CV & & 19.6 & & 16 \\
\hline
\end{tabular}

$\mathrm{Ns}=$ non-significant,$* *=$ significant at $\mathrm{P}=0.01$ and $* * *=$ significant at $\mathrm{P}=0.001, \% \mathrm{cv}$ - coefficient of variation (percentage)

ranged between 43 (CNF5520) to 122 minutes (RWR2154) with an average time of 73 minutes. This represented $1 \%(<45$ minutes), 24\% (46-60 minutes) and 74\% (>60 minutes). Awash melka and VAX4 cooked for 51 and 114 minutes, respectively.

A total of 15 genotypes (Amahunja, Awash melka, Bihogo, $\mathrm{CAB}$ 2, ECAPAN021, G858, Icaquimbaya, KK20, NABE12C, NABE4, NABE6, ROBA-1, RWR1873, RWV3006) were consistent in short cooking time for the two seasons and had a Fe content above the low Fe check (CAL96 - 55 mg $/ \mathrm{kg}$ ). However, some genotypes were long cooking ( $>60$ minutes) for both seasons (Table 4).

The analysis of variance (Table 5) showed that the genotypes differed significantly for $\mathrm{Fe}$ and $\mathrm{Zn}$ seed content. The genotype effect was highly significant $(\mathrm{P} \leq 0.001)$ for both seed $\mathrm{Fe}$ and $\mathrm{Zn}$ contents in the bush type but non-significant for climbers. Season effect was only significant for Fe concentration in bush beans, though effect of replications within seasons was significant for both $\mathrm{Fe}$ and $\mathrm{Zn}$ in bush and climber $(\mathrm{P}<0.001)$ and $(\mathrm{P}<0.05)$ respectively. However, the interaction between genotype and season was not significant for both bean types. The analysis was done on plot basis hence the replications ensured good experimental precision.

For season 2015B, Fe content ranged from 46-88 $\mathrm{mg} / \mathrm{kg}$, with an average of $64 \mathrm{mg} / \mathrm{kg}$ while Zn content varied at $24-40 \mathrm{mg} / \mathrm{kg}$ with an average of $30 \mathrm{mg} / \mathrm{kg}$. During the season 2015D, Fe content ranged from $39-75 \mathrm{mg} / \mathrm{kg}$ with an average of $58 \mathrm{mg} / \mathrm{kg}$ while $\mathrm{Zn}$ content was between $26-42 \mathrm{mg} / \mathrm{kg}$ with an average of $33 \mathrm{mg} / \mathrm{kg}$.

Across the two seasons (Table 6), the 152 common bean genotypes showed a wide variability in both the Fe and $\mathrm{Zn}$ content. The Fe content ranged between $39-86 \mathrm{mg} / \mathrm{kg}$ with an average mean of $60 \mathrm{mg} / \mathrm{kg}$ for bush beans while the Zn content ranged between $24-40 \mathrm{mg} / \mathrm{kg}$ with an average of $31 \mathrm{mg} / \mathrm{kg}$ (Table 6). A total of 61 bush genotypes had Fe content above the universal high Fe check (RWR2154) which had an average of $69 \mathrm{mg} / \mathrm{kg}$. On the other hand, Fe and Zn seed content among the climbers ranged between $46-88 \mathrm{mg} / \mathrm{kg}$ with an average of $66 \mathrm{mg} / \mathrm{kg}$ for Fe while $\mathrm{Zn}$ ranged between $27-42 \mathrm{mg} / \mathrm{kg}$ and average of $34 \mathrm{mg} / \mathrm{kg}$. Two genotypes (Nakaja and CAB2) had Fe content higher than the universal high Fe check (MIB 465) which had a concentration of $80 \mathrm{mg} / \mathrm{kg}$ for the first season while Nakaja $(79 \mathrm{mg} / \mathrm{kg}$ ) performed at per with the check (MIB $465-79 \mathrm{mg} / \mathrm{kg}$ ).
Table 4: Seasonal performance of genotypes for cooking time

\begin{tabular}{|c|c|c|c|c|c|c|}
\hline \multirow{2}{*}{$\begin{array}{l}\text { GENOTYPE } \\
<60 \text { minutes }\end{array}$} & \multicolumn{2}{|c|}{ Season 2015B } & \multicolumn{2}{|c|}{ Season 2015D } & \multicolumn{2}{|c|}{ Average } \\
\hline & CT (mins) & Rank & CT (mins) & Rank & CT (mins) & Rank \\
\hline Amahunja & 42 & 6 & 52 & 6 & 47 & 6 \\
\hline Awash melka & 35 & 1 & 51 & 5 & 43 & 2 \\
\hline Bihogo & 45 & 9 & 53 & 7 & 49 & 8 \\
\hline CAB 2 & 45 & 9 & 41 & 1 & 43 & 2 \\
\hline CNF5520 & 41 & 5 & 43 & 2 & 42 & 1 \\
\hline ECAPAN 021 & 47 & 11 & 59 & 13 & 53 & 12 \\
\hline G858 & 44 & 8 & 58 & 12 & 51 & 10 \\
\hline Icaquimbaya & 46 & 10 & 57 & 11 & 52 & 11 \\
\hline KK20 & 50 & 14 & 57 & 11 & 53 & 12 \\
\hline NABE12C & 42 & 6 & 60 & 14 & 51 & 10 \\
\hline NABE4 & 45 & 9 & 59 & 13 & 52 & 11 \\
\hline NABE6 & 42 & 6 & 49 & 4 & 45 & 5 \\
\hline ROBA-1 & 44 & 8 & 60 & 14 & 52 & 11 \\
\hline RWR 1873 & 38 & 3 & 58 & 12 & 48 & 7 \\
\hline RWV3006 & 46 & 10 & 54 & 8 & 50 & 9 \\
\hline \multicolumn{7}{|l|}{$>60$ minutes } \\
\hline VAX4 & 100 & 47 & 108 & 53 & 104 & 55 \\
\hline KATX56 & 92 & 46 & 106 & 52 & 99 & 53 \\
\hline Kanyebwa & 84 & 42 & 98 & 47 & 91 & 49 \\
\hline NABE8C & 71 & 32 & 110 & 55 & 91 & 49 \\
\hline NABE3 & 71 & 32 & 109 & 54 & 90 & 48 \\
\hline RWR 1092 & 75 & 36 & 105 & 51 & 90 & 48 \\
\hline TO & 83 & 41 & 94 & 44 & 88 & 47 \\
\hline AND 1062 & 68 & 30 & 115 & 59 & 92 & 50 \\
\hline KATB1 & 70 & 31 & 79 & 31 & 75 & 34 \\
\hline KATB9 & 63 & 26 & 103 & 50 & 83 & 43 \\
\hline KATX69 & 63 & 26 & 69 & 21 & 66 & 25 \\
\hline M'sole & 73 & 34 & 78 & 30 & 76 & 36 \\
\hline $\begin{array}{l}\text { Masindi } \\
\text { Yellow Short }\end{array}$ & 71 & 32 & 90 & 40 & 80 & 40 \\
\hline NABE15 & 74 & 35 & 70 & 22 & 72 & 31 \\
\hline NABE16 & 77 & 37 & 108 & 53 & 93 & 51 \\
\hline NABE19 & 78 & 38 & 85 & 37 & 82 & 41 \\
\hline GLP585 & 88 & 45 & 70 & 22 & 79 & 39 \\
\hline FLOR DE & 87 & 44 & 92 & 42 & 90 & 48 \\
\hline MAYO & & & & & & \\
\hline RWR 719 & 85 & 43 & 84 & 36 & 84 & 44 \\
\hline
\end{tabular}

Table 5: Mean squares for seed Fe and Zn content $(\mathrm{mg} / \mathrm{kg})$ of 121 bush and 31 climbing bean genotypes

\begin{tabular}{lcccccccc}
\hline SOV & \multicolumn{4}{c}{ Bush } & & \multicolumn{3}{c}{ Climbers } \\
\cline { 2 - 4 } \cline { 7 - 9 } & DF & $\mathrm{Fe}$ & $\mathrm{Zn}$ & & DF & $\mathrm{Fe}$ & $\mathrm{Zn}$ \\
\hline Season & 1 & $11347^{*}$ & 330 & & 1 & 491 & 1124 \\
Rep (Season) & 4 & $1144^{* * *}$ & $846^{* * *}$ & & 4 & $334^{*}$ & $95^{* *}$ \\
Genotype & 120 & $308^{* * *}$ & $43^{* * *}$ & & 30 & 151 & 20.7 \\
Genotype. Season & 122 & 1750 & 6.9 & & 30 & 69 & 21 \\
LEE & $65-77$ & 15.4 & 3,4 & & $28-30$ & 35,7 & 2.3 \\
SED & & 3 & 2 & & 5 & 1 \\
\%CV & & 6 & 5 & & 8 & 4 \\
\hline
\end{tabular}

$\mathrm{Ns}=$ non-significant $* *$ significant at $\mathrm{P}=0.01$ and $* * *=$ significant at $\mathrm{P}=0.001, \% \mathrm{cv}$ - coefficient of variation (percentage)

Across the seasons, the genotypes varied in the Fe and $\mathrm{Zn}$ concentration. The genotypes level of $\mathrm{Fe}$ content decreased from season one to the second season while $\mathrm{Zn}$ content levels increased. Six genotypes (CAB 2, RWR2154, CNF5520, Awash melka, KATB9) had high mineral content across the two seasons and a short cooking time (Table 7). A strong positive correlation existed between $\mathrm{Fe}$ and $\mathrm{Zn}$ content, $r=0.71(\mathrm{P}<0.001)$. Nevertheless, the correlation 
Table 6 : Distribution of seed Fe and $\mathrm{Zn}$ concentration in tested bean genotypes

\begin{tabular}{lcccccc}
\hline Bean type & Number of genotypes & Season & Fe (ppm) range & Zn (ppm) range & Fe content of high Fe check & $\begin{array}{c}\text { Number of genotypes with } \\
\text { Fe }>\text { high Fe check }\end{array}$ \\
\hline Bush & 121 & l (2015B) & $46-86$ & $24-37$ & 81 (RWR2154) & 2 \\
\multirow{2}{*}{ Climber } & \multirow{2}{*}{31} & $2(2015 \mathrm{D})$ & $39-75$ & $26-40$ & 59 (RWR2154) & 59 \\
& & $1(2015 \mathrm{~B})$ & $55-88$ & $27-40$ & 85 (MIB465) & 1 \\
\hline
\end{tabular}

Table 7 : Seasonal performance in Iron and Zinc for selected genotypes

\begin{tabular}{|c|c|c|c|c|c|c|}
\hline \multirow[t]{3}{*}{ Genotype } & \multicolumn{6}{|c|}{ Micronutrient content } \\
\hline & \multirow{2}{*}{$\frac{2015 \mathrm{~B}}{\mathrm{Fe}}$} & \multirow{2}{*}{$\frac{2015 \mathrm{D}}{\mathrm{Fe}}$} & \multirow[t]{2}{*}{ Average $\mathrm{Fe}$} & \multirow{2}{*}{$\frac{2015 B}{Z n}$} & \multirow{2}{*}{$\frac{2015 \mathrm{D}}{\mathrm{Zn}}$} & \multirow[t]{2}{*}{ Average $\mathrm{Zr}$} \\
\hline & & & & & & \\
\hline ACC714 & 86 & 75 & 81 & 33 & 35 & 34 \\
\hline NAKAJA & 84 & 75 & 79 & 34 & 37 & 36 \\
\hline MIB 465 & 85 & 74 & 79 & 35 & 40 & 37 \\
\hline JESCA & 84 & 72 & 78 & 34 & 37 & 35 \\
\hline CAB 2 & 88 & 66 & 77 & 38 & 38 & 38 \\
\hline VAX5 & 80 & 69 & 74 & 31 & 33 & 32 \\
\hline VAXI & 73 & 74 & 74 & 34 & 39 & 37 \\
\hline Mexico 142 & 79 & 67 & 73 & 33 & 37 & 35 \\
\hline VAX2 & 77 & 67 & 72 & 32 & 34 & 33 \\
\hline AND 620 & 74 & 69 & 71 & 35 & 40 & 38 \\
\hline RWR 719 & 73 & 68 & 71 & 32 & 36 & 34 \\
\hline VCB81013 & 73 & 68 & 71 & 33 & 42 & 38 \\
\hline GITANGA & 71 & 70 & 71 & 32 & 40 & 36 \\
\hline MCM 2001 & 71 & 69 & 70 & 30 & 32 & 31 \\
\hline RWV3006 & 80 & 59 & 70 & 40 & 30 & 35 \\
\hline NABE29C & 74 & 65 & 69 & 31 & 37 & 34 \\
\hline NABE3 & 72 & 67 & 69 & 30 & 34 & 32 \\
\hline RWR2154 & 81 & 57 & 69 & 34 & 32 & 33 \\
\hline NABE26C & 72 & 65 & 69 & 31 & 38 & 35 \\
\hline VAX6 & 74 & 63 & 68 & 32 & 32 & 32 \\
\hline CNF5520 & 73 & 63 & 68 & 36 & 40 & 38 \\
\hline RWR 2245 & 70 & 67 & 68 & 31 & 37 & 34 \\
\hline NABE22 & 71 & 64 & 67 & 37 & 36 & 37 \\
\hline MAC 44 & 71 & 63 & 67 & 29 & 36 & 32 \\
\hline $\begin{array}{l}\text { Awash } \\
\text { melka }\end{array}$ & 69 & 64 & 67 & 29 & 32 & 30 \\
\hline A344 & 71 & 62 & 67 & 32 & 36 & 34 \\
\hline ROBA-1 & 70 & 62 & 66 & 32 & 33 & 33 \\
\hline BIHOGO & 70 & 60 & 65 & 33 & 35 & 34 \\
\hline SAB 686 & 69 & 56 & 63 & 31 & 34 & 32 \\
\hline Kanyebwa & 57 & 49 & 53 & 26 & 28 & 27 \\
\hline КАТВ9 & 56 & 45 & 51 & 28 & 28 & 28 \\
\hline NUA8 & 53 & 48 & 51 & 24 & 29 & 27 \\
\hline NABE20 & 52 & 46 & 49 & 26 & 30 & 28 \\
\hline Mean & 72.8 & 63.5 & 68.1 & 32.0 & 34.8 & 33.4 \\
\hline SED & 7.9 & 7.5 & 7.2 & 3.2 & 3.6 & 3.0 \\
\hline
\end{tabular}

* Names in bold indicate genotypes with high Fe and short cooking time, $\mathrm{SED}=$ standard error of difference

between cooking time and $\mathrm{Fe}$ and $\mathrm{Zn}$ was negative (-0.04 and 0.04 , respectively).

\section{DISCUSSION}

This study was done to ascertain the variability for cooking time, Fe and $\mathrm{Zn}$ content in common bean genotypes and to identify genotypes with short cooking time, high Fe and high Zn content. The genotypes evaluated showed a great diversity for these traits. Cooking time ranged from 35 to 100 minutes during the first season and between 43 to 122 minutes during the second season with an average cooking time of 56 and 73 minutes respectively. Across the two seasons, the average cooking time was 66 minutes, Seasonal differences might have resulted from variations in the amount of rainfall, temperature and relative humidity. The first season experienced a higher amount of rainfall $(690 \mathrm{~mm})$ as compared to second season (489 mm).

The genotype by season interaction was significant for cooking time implying a contribution of seasons to differences in cooking time. This interaction may be explained by the possibility of interference of environmental conditions with genotypes in alteration of the grain tegument integrity, resulting in changes in their ability for water absorption and cooking time as reported by Carbonell (2003). Zilio et al. (2014) showed that temperatures lower than $30^{\circ} \mathrm{C}$ and air humidity higher than $40 \%$ during grain filling is ideal for lower cooking time in beans. Cooking time is also affected by the amount of rainfall per season. The first season had higher rainfall hence short cooking time among the genotype unlike the second season where the cooking time increased among the genotypes.

The test genotypes showed a wide range for both $\mathrm{Fe}$ and $\mathrm{Zn}$ content indicating the possibility of breeding for increased $\mathrm{Fe}$ and $\mathrm{Zn}$ content in common bean genotypes. The range of $\mathrm{Fe}$ and $\mathrm{Zn}$ observed in this study was comparable to one reported by Mukamuhirwa et al., (2015) and Blair et al., (2010). There were notable differences in the micronutrient concentration of the seeds between the seasons. These differences could have resulted from the seasonal variations (amount of rainfall) and the soil characteristics during each season. In addition, the climbers had a higher Fe concentration than the bush bean for the two seasons. This is attributed to the longer days taken in the field by climber beans denoting the differences in the uptake and loading of $\mathrm{Fe}$ and $\mathrm{Zn}$ in common bean (Mukamuhirwa et al., 2015).

In this study $\mathrm{Fe}$ and $\mathrm{Zn}$ showed a strong positive correlation $(\mathrm{r}=0.71)$ supporting the study of Nchimbi-Msolla and Tryphone, (2010) who observed the strong positive correlation of $\mathrm{Fe}$ and $\mathrm{Zn}$ in what in common bean. In addition, a study by Mukamuhirwa et al., (2015) reported a positive strong correlation between $\mathrm{Fe}$ and $\mathrm{Zn}(\mathrm{r}=0.75)$. The positive and highly significant correlation between the Fe and $\mathrm{Zn}$ concentrations in seeds of bean suggests that genetic factors that increase $\mathrm{Fe}$ concentration co-segregate with genetic factors that increase $\mathrm{Zn}$ concentration, therefore selecting for bean seeds with high concentration of either Fe or Zn may contain high amounts of both elements (Nchimbi-Msolla and Tryphone, 2010). The correlation between cooking time to both Fe and Zn was relatively low. 
The wide genetic variability observed in this study might be revealing a possibility of a diversity of bean genotypes in the greater Eastern Africa region; and therefore existence of valuable alleles for bean improvement including nutritional breeding. Great variability among genotypes allows selection of those with reduced cooking time. Among these, a total of 35 genotypes had good combination of high $\mathrm{Fe}$ and $\mathrm{Zn}$ content with short cooking time.

\section{CONCLUSION}

From this study, it is concluded that genetic variability for the cooking time, $\mathrm{Fe}$ and $\mathrm{Zn}$ content traits is sufficient to make breeding progress. In addition, some genotypes were short cooking and had high Fe and Zn content. This signifies the ability to combine these traits in a genotype. However, more studies are necessary to exploit any possible interactions of these traits at advanced generations probably $\mathrm{F}_{4}$ to $\mathrm{F}_{6}$. The biochemical components as well as other factors both genetic and environmental affecting cooking time, Fe and $\mathrm{Zn}$ content should as well be exploited.

\section{ACKNOWLEDGEMENTS}

The authors are grateful to Makerere University, Alliance for a Green Revolution in Africa (AGRA), International Center for Tropical Agriculture (CIAT) and Rwanda Agricultural Board (RAB) for the support to this work.

\section{REFERENCES}

Blair, M. W., González, L. F., Kimani, P. M., \& Butare, L. (2010). Genetic diversity, inter-gene pool introgression and nutritional quality of common beans (Phaseolus vulgaris L.) from Central Africa. TAG. Theoretical and Applied Genetics, 121(2), 237-248. https://doi. org/10.1007/s00122-010-1305-x
Carbonell, S. C. (2003). Cooking quality parameters of common bean genotypes, sown in different seasons and locations. Bragantia, 62, 369-379.

Elia, F. M. (2003). eritability of cooking time and water absorption traits in dry beans (Phaseolus vulgaris) using a North Carolina mating scheme II. Tanzania Journal of Science, 29, 25-35. https://doi.org/10.4314/ tjs.v29i1.18364

Gerwing, J., \& Gelderman R. (2005). Fertilizer recomendations Guide. Cooperative Extension service (pp 1-28).South Dakota State University, United States Department of Agriculture.

Mukamuhirwa, F., Tusiime, G. \& Mukankusi, M.C. (2015). Inheritance of high iron and zinc concentration in selected bean varieties. Euphytica 205, 349-360. https://doi.org/10.1007/s10681015-1385-4

Nchimbi-Msolla, S., \& Tryphone, G. M. (2010). The effects of the enviroment on the iron and zinc concentration and performance of common bean (Phaseolus vulgaris) genotypes. Asian Journal of Plant Sciences, 9 , 455-462. https://doi.org/10.3923/ajps.2010.455.462

Okalebo, J. R., Gathua, K. W., \& Woomer, P. L. (2002). Laboratory Methods of Soil and Plant Analysis. Nairobi, Kenya: TSBF-CIAT and SACRED Africa.

Oxford-Instruments X Supreme 800 users guide (2009). The Business of Science. Accessed from https://www.oxford-instruments.com

Paltridge, N., Palmer, L., \& Stangoulis, J. (2011). Micro-nutrient analysis in the HarvestPlus program, Rwanda. HarvestPlus. Rwanda: Harvest plus Training on how to use XFR machine.

Proctor, J. R., \& Watts, B. M. (1987). Development of a Modified Mattson Bean Cooker Procedure Based on Sensory Panel Cookability Evaluation. Canadian Institute of Food Science and Technology Journal, 20(1), 9-14. https://doi.org/10.1016/S0315-5463(87)70662-2

Stangoulis. (2010). Technical aspects of Zn and Fe analysis in biofortification of staple food crops. Wheat and Rice 19th World Congress of soil science for a changing world. Brisbana Australia.

USAID. (2016). Uganda : Nutrition Profile.lavailable from https://www usaid.gov/what-we-do/global-health/nutrition/countries/ugandanutrition-profile.

Wang, N., \& Daun, J. (2005). Determination of cooking time of pulses using an automated Mattson cooker apparatus. Journal of the Science of Food and Agriculture, 85, 1631-1635. https://doi.org/10.1002/ jsfa.2134

Zilio, M., Souza, C. A., Coelho, C. M. M., \& Miquelluti, D. J. (2014). the genotype and crop environment affect the technological quality of common beans grains. American-Eurasian Journal of Agriculture \& Enviromental Science, 14, 212-220. https://doi.org/10.5829/idosi. aejaes.2014.14.03.12315 